\title{
Reframing Interfaith Boundary Crossing and Maintenance: Middle Eastern Christians' Narratives on Intimacy with Muslims
}

\author{
Anne Rosenlund Jørgensen
}

\begin{abstract}
By exploring narratives of Middle Eastern Christians (MECs) in Denmark I want to open an important, yet overlooked, window on invisible intra-ethnic relations in an immigrant context in Denmark. The subject of research is negotiations of boundary maintenance and strategies for recovering from boundary crossings in cases of interfaith intimacies between MEC women and Muslim men in Denmark. The research focuses on different contextual aspects of intimate boundary crossing and argues that already at the stage of dating, the relationship challenges boundaries and erodes families and communities. In order to explore some very diverse narratives, I ask: How do MECs in Denmark, who carry experiences of intra-ethnic interfaith intimacies with Muslims, negotiate boundary maintenance at the levels of the individual, the family and the MEC community?
\end{abstract}

"Well, we have lived together in the Middle East since many years ago. (...) What is it about the two of us that makes us different from each other? Well, of course it is religion". (Assyrian Priest in Denmark)

This quote is from an interview conducted by a colleague in the research project DIMECCE ${ }^{1}$ with the priests of the Assyrian Church of the East in Denmark elaborating on the relationship between Christian and Muslim immigrants in Denmark from the Middle East. In his words, religion is what separates the two groups from each other and implicitly he argues that if you remove religious affiliation, they are 'the same'. This attitude towards a demarcation between the two groups is seen among Christians in the Middle East as a twofold strategy: being a Christian minority and 'different' to the majority, but 'the same' in regard to national and/or ethnic identification (Galal 2012).

Public and scholarly attention to the relationship between Christian and Muslim immigrants from the Middle East in Denmark has been absent, probably mostly due to a tendency in Denmark to

\footnotetext{
1 The HERA financed project Defining and Identifying Middle Eastern Christian Communities in Europe. See official webpage: https://arts.standrews.ac.uk/dimecce/ (Accessed 29 September 2015)
} 
disregard religious difference among Middle Eastern immigrants, who are regarded as 'the same' (Sparre et. al. 2015) and as such MECs remain invisible within a perceived Middle Eastern Muslim immigrant group. However, on the topic of Christians in the Middle East, there have been a few articles in the local media recently featuring violent harassment of MECs by Muslim groups in Denmark (Johansen 2014, Khader 2014).

In general though, intra-ethnic interfaith relations elicit neither public nor scholarly attention, because they do not symbolise a socalled clash between something Danish (white) and something ethnic (brown or black). Immigrants from the Middle East, whether they are Christian or Muslim, are both conceived as 'the significant other' in the public mainstream attention and thus regarded as 'the same' (Hunter \& McCallum 2014, Sparre, Galal \& Jørgensen forthcoming). Therefore, this article's aim is to direct scholarly attention to the under-researched subject of intra-ethnic negotiations of MEC relations with Muslims in Denmark, and to open an important window on hitherto invisible intergroup relations and boundary negotiations within an immigrant context. Through a new analysis of narratives of MECs gathered during my time at the Danish component of the first research project exploring MEC immigrant communities, Defining and Identifying Middle Eastern Christian Communities in Europe (DIMECCE), I take a look at the invisible subject of inter-faith intimacy as an act that challenges boundaries across levels of community, family and individual (Connolly 2009, Galal 2009).

\section{Studies of Middle Eastern Christians in Denmark}

DIMECCE explores migrant experiences of MECs in UK, Sweden and Denmark. ${ }^{2}$ I have been affiliated with the Danish component at Roskilde University since late 2014. In this time I wrote a Master's thesis based on five interviews ${ }^{3}$ I conducted to explore narratives of MECs who had opted out of either Orthodox or Catholic MEC communities in Denmark, namely the Coptic Orthodox Church ${ }^{4}$, the Chaldean Catholic Church, the Assyrian Church of the East, and the Ancient Church of the East ${ }^{5}$. I found that the reasons for leaving were

\footnotetext{
${ }^{2}$ See official web page of the research project: $\mathrm{https}: / /$ arts.standrews.ac.uk/dimecce/ (Accessed 29 September 2015)

${ }^{3}$ The interviews were conducted as semi-structured and open ended and they lasted between 1- 2,5 hours.

${ }^{4}$ Most Christian Egyptians belong to the Coptic Orthodox Church, which was established in $42 \mathrm{AD}$. Today it is a diasporic Church with congregations all over the world. The Danish Coptic Orthodox Church is located in Taastrup. Read more: Sparre et. al. 2015.

${ }^{5}$ The Iraqi Christians in Denmark belong to the Chaldean Catholic Church with churches in Aarhus and Copenhagen, or the Assyrian Church of the East in Aarhus, or the Ancient Assyrian Church of the East. The latter two are Orthodox whereas the Chaldean Church is Catholic. Read more: Sparre et. al.
} 
multiple and that it was not always pure choice; rather, for some of the interviewees, it followed from experiences of social exclusion from the MEC communities, and this social exclusion in turn was due to direct or indirect intimate relations with Muslims. Thus, the thesis made interesting reading as it revealed hidden and unofficial policies of some of the established MEC communities in Denmark. These policies are worth studying further to explore the boundaries between Christians and Muslims from the Middle East in Denmark and challenges to them.

My research draws on interviews with three MECs who experienced intra-ethnic interfaith intimacy - either directly or indirectly - with Muslims in Denmark. The first lays the foundation as it explores how an individual negotiates boundary maintenance and crossing and recovers from the consequences, whereas the last two interviews are with parents whose daughters were dating Muslim men. An analysis of the narratives points to the need for exploring intra-ethnic interfaith intimate relations further in future research, as religious immigration and translocation forces new perspectives and puts new pressures on the boundaries between these two groups who have lived together for centuries, and on the processes of their reproduction and maintenance (Barth 1994). Of particular interest is the sense of invisibility of the MECs within the new Danish context.

The subject of interfaith intimacies refers to the private sphere and consequently methodological and ethical considerations arise, such as a need for anonymisation and sensitivity regarding dissemination. Therefore I have totally anonymised the interviewees and removed information regarding name, age, denominational belonging, city of residence, time of arrival in Denmark and occupation. However, these deletions are not without consequences for the research result because important aspects of analysis may be lost and interesting comparative elements perforce left unexplored. As an example it would be interesting to explore differences in boundary maintenance and policies of interfaith intimacies between the MEC communities in Denmark as in many respects they originate from different religious, political and (im)migrant contexts, mainly Iraq and Egypt (Sparre et. al. 2015).

\section{Towards a definition of invisible intra-ethnic interfaith intimacies}

"Crossing boundaries sexually in the form of intermarriage challenges the communities, blurring their boundaries, eroding their cultural distinctiveness, and, in the case of minorities, jeopardizes their survival. Communities harbour a vital interest 
in controlling this threat through sexual prescription that can help establish and sustain a particular political order". (Connolly 2009: 504)

Aaron, a middle-aged Christian from the Middle East living in Denmark, was actively involved in one of the MEC communities ${ }^{6}$ until recently, when he discovered that his daughter was dating a young Muslim man of Middle Eastern origin - a relationship he was furious about when I interviewed him. Not only did it affect the internal relationship between members of the family negatively, it also affected the status of the parents within the MEC community they had been involved in all of their lives, whether in Denmark or in the Middle East. They now experienced social exclusion, both from the community members and the priest. As such, indirect interfaith intimacies with Muslims (by being the parent of a daughter having direct interfaith intimacy with a Muslim) caused social exclusion from the community. He exemplifies by explaining how members of the community talk behind his back: "They all talk about (name of his daughter) and her problems - well you must excuse me - like bitch". Aaron, although he himself did not cross the interfaith boundary, experiences the MEC community's policy towards boundary crossing: because it threatens the community, he as a parent is socially excluded and given the responsibility of either terminating his daughter's relationship with the Muslim man or breaking his own contact with her. His example shows us how intimate boundary crossing becomes a challenge not only to the individual and her parents, but also to the community. As such an exploration of negotiations on boundary maintenance and the struggle for 'survival' on individual, family and community levels is relevant. In this article I explore only the negotiations from an individual and parental perspective, but I strongly recommend that this is explored further by including a comparative analysis of the communities' negotiations of boundary maintenance across denominations.

\section{Interfaith intimacies}

Aaron's narrative exemplifies how interfaith relationships are already problematic as early as the dating stage. It also highlights how intimate romantic boundary crossing - that is, a possible marriage in embryo - does not affect only the involved parties: it is seen as a

\footnotetext{
${ }^{6}$ In Denmark there are four identified "traditional" Middle Eastern Christian communities: the Assyrian Orthodox community represented by both the Assyrian Church of the East and the Ancient Church of the East; the Chaldean Catholic community represented by two churches, on in Aarhus and one in Copenhagen and five small congregations in other parts of Denmark; the Coptic Orthodox community with a church in Copenhagen, and finally the Syriac Orthodox community, which has just established a congregation in Næstved.
} 
threat, something that challenges and even erodes both the family and the wider community. As such, the body of the daughter and the possible sexual boundary crossing between her and her Muslim boyfriend becomes a symbolic boundary marker of the body politics within the socio-political environment of the community and family (Connolly, 2009: 499). Therefore, instead of working with the term interfaith marriages, as Connolly (2009), Singla (2012) and Galal (2009) do, I subscribe to the term interfaith intimacies, since I argue that interfaith relationships begin to disturb and erode the boundaries of communities and families back in their tentative beginnings when they cease to be platonic. In other words, already at the stage of falling in love, dating or becoming boyfriend and girlfriend, the individual, the family and the community are affected and jeopardised.

In an immigrant context, most research in Denmark on interfaith intimacies has concentrated on ethnically mixed marriages - for example a marriage between a white (often secular or Christian) and an ethnic immigrant minority (often Muslim, Hindi, etc.) (Singla 2015, Poulsen 2012, Rytter 2007). Miri Song (2012) problematises this aspect and points towards a tendency to overlook important research on immigrant groups when the focus is on two significantly different groups. She asks: "How should we conceive of the experiences of people who are mixes of two non-white groups?" (Song 2012: 569). Connolly (2009) is one of the few researchers exploring intra-ethnic marriages crossing religious boundaries. She focuses on Christian Protestant converts in Indonesia marrying Muslim compatriots; her research therefore does not cover interfaith marriage in an immigrant perspective. Galal (2009) also explores intra-ethnic interfaith marriages, but her research is among Coptic Christians and Muslims living in Egypt. Thus, research on intra-ethnic interfaith intimacies has been on marriages in the lands of origin. What remains rather unexplored is how an intra-ethnic group explores interfaith boundary crossings in a context of migration.

Muslims and Christians as an intra-ethnic group? Ambivalence and challenges in terminology

Importantly, the argument that Middle Eastern immigrants share ethnicity is a highly contested statement and a rather vulgarised claim. I argue that they all experience this simplification in a 'Western' society because in media and society, MECs are invisibilised racialised and perceived as a mono-ethnic group: Muslims. As an example, almost without exception, all MECs interviewed in the DIMECCE project had experienced being mistaken for a Muslim because of their Middle Eastern or Arabic appearance (Hunter \& McCallum 2014, Sparre, Galal \& Jørgensen forthcoming). 
2015). Thus, the religious differences are publicly invisible and the Middle Eastern 'Muslim' visual characteristics salient.

What is needless to emphasise is that many MECs would deny the claim that they share ethnicity, origin or even nation. As an example, an Assyrian from Iraq would probably deny the fact that they and Muslims share the same country of origin, since they originate from Assyria and not Iraq. Moreover, many Iraqi Christians would deny an Arabic ethnicity, saying it is a Muslim ethnicity, whereas many Coptic Christians would be more inclined to use it.

Thus, it is hard to capture a term that is able to contain the ambivalences, policies and strategies within different MEC communities. However, since they share some appearance traits with most Middle Eastern Muslims I use 'Middle Eastern' ethnicity as a definition of intra-ethnicity to capture the diverse group of people in Denmark who originate from the Middle East and are considered 'the same', even though it is an oversimplification of an extremely complex group.

\section{Capturing narratives on intra-ethnic interfaith intimacies}

Having clarified terminology with certain reservations, I present the research question, which is: How do MECs in Denmark, who carry experiences of intra-ethnic interfaith intimacies with Muslims, negotiate boundary maintenance on the levels of the individual, the family and the MEC community?

To be able to capture the diversity and complexity within and between the narratives, I use Michael Jackson's approach to analyse the narratives as storytelling:

In so far as tragedy has the effect of sending one deep into oneself, it is characterized by social withdrawal, silence, and retreat. Storytelling brings one out of oneself. It involves a decision to speak out, to share one's story with others, to see one's situation from afar, and even, in time, to see its comic side. Accordingly, the tragic and the comic cannot be treated as distinct genres, but as terms that mark the opposite ends of a continuum. (Jackson, 2012: 184-185)

Using this claim that storytelling is a means to recover (Jackson 2012) I approach narratives as dynamic and process-related, thus a continuum, not a genre. My analysis is twofold: one of my interviewees is a middle-aged MEC woman who has been in a relationship with a Muslim man in Denmark with whom she has two children. An analysis of her interview revolves around the individual perspective on intra-ethnic interfaith boundary crossing and boundary negotiations and her narrative shows how she has recovered from the consequences of intimate boundary crossing. The last two interviews constitute the parental perspective: both parents are affected by their daughter's intimate relations with a Muslim man and the narratives reveal how the parents and the whole family are affected by a 
daughter's boundary crossing and the community's policy to survive. The analysis of all three narratives underlines the argument that not only is marriage a boundary marker, but already at the stage of dating the interfaith boundary has been crossed and the challenges appear.

\section{The situational context of Middle Eastern Christians in Denmark and interfaith relations}

This article derives inspiration from Connolly's (2009) study of intraethnic interfaith boundary crossing among compatriots in Indonesia. She subscribes to Barth's (1994) focus on boundaries and the diacritic marks that separate and differentiate groups or communities, rather than the cultural content enclosed by the boundaries. He argues that the processes of boundary maintenance are highly situational, and it is from this point of departure that I focus on contextual aspects in the narratives of MECs as they negotiate their individual and parental processes of boundary maintenance within the blurred area caused by interfaith intimacies in Denmark.

Below, I briefly outline the situational and contextual elements in these three narratives.

Firstly, the MEC communities have a long history in Iraq and Egypt, where the legislation on boundary crossing in the form of marriage gave preferential treatment to the Muslim majority. In Egypt, a Coptic woman converting to Islam could not be forbidden to marry by her parents (Galal 2012); in other words the parents lost authority over their child, and hence were likely to fight the conversion bitterly. In Iraq, the Baath party's legislation on interfaith marriage automatically converted a woman and her children to Islam if she married a Muslim man (Hanish 2009). In other words Islam as a religion is given preference by the marriage legislation in both countries, giving Christian minorities strong incentive to fight conversion and interfaith marriage. As such, most church institutions have strategically worked as socio-political actors, embedding the same policies on interfaith marriage in order to comply with national rules and conform nationally and ethnically with the majority (Galal, 2012).

Secondly, the MECs are affected by the Danish official and public attitude towards interfaith intimacies and/or marriages. Even though the Danish state has comprehensive marriage legislation ${ }^{7}$ it does not regard religious difference as problematic. As such, the MEC communities are placed within a new political context that either renders interfaith marriage completely invisible or disregards it as an unimportant detail. However, although only forced marriage is

7 See the Danish legislation on marriages: https://www.retsinformation.dk/Forms/R0710.aspx?id=163352 (Accessed 13 November 2015). 
formally illegal a fairly pervasive attitude among ethnic Danes looks down on the institution of arranged marriage and associates it with something un-Danish and Muslim (Schmidt, 2011).

Thirdly, The MECs carry a long history of relations with Muslims and a lot has been written about their history as neighbors and compatriots (Cragg 1991, Greene 2000, Hasan 2003, Hanish 2009). In interviews for the DIMECCE project, MECs living in Denmark all somehow related to their shared history with a Muslim population in the Middle East. Many of them argued that history was repeating itself with regard to persecution of Christians, citing the current attacks on Christians by ISIS in the region. Hunter and McCallum (2014), who constitute the UK component of the DIMECCE research team, have studied UK-based MEC immigrant attitudes towards their Muslim immigrant compatriots. They argue that MECs are not only sometimes the mistaken objects of Islamophobic discourse due to similar visual appearance, but also constitute a population where anti-Muslim prejudice is prevalent. Having read most interviews done by the Danish component of the DIMECCE research team, I would argue that the results could be similar in a Danish context. However, and most importantly, MECs all respond to the topic on relations with Muslims in Denmark, whether positive or negative, and most respond to their shared experience of mis-identification as Muslims from the general public. There is a tendency in most interviews to regard Muslims as 'the significant other', rather than the ethnically 'white' (secular/Christian) Dane and many tell stories of having fled from Muslims and of seeking refuge in an anticipated Christian country. In this regard, the history of Muslim-Christian relations is present and certainly reproduced in the narratives of MECs in Denmark.

Fourthly, the positions of MECs are turned upside down: in the Middle East they appeared as a religious minority within the national and/or ethnic majority, whereas in Denmark they are part of an 'ethnic' minority within a religious majority in Denmark. However most MECs distinguish between a Danish Christianity and a Middle Eastern Christianity as two different versions, the latter being more morally founded and consequently, most MECs might regard themselves as part of a minority within a minority. According to Barth (1994) the double minority aspect intensifies a group's struggle for survival as a community and the importance of boundary maintenance becomes even more pivotal.

Fifthly, the issue of interfaith intimacies is not neutral when it comes to gender. Much research on interfaith marriage, intimacy and sexual boundary crossing has demonstrated how often women become the symbolic boundary marker due to their biological capacity as child-bearers and their social role in communities, where they often raise the children culturally and religiously (Anthias and Yuval-Davis 1989; Connolly 2009; McClintock 1997; Scheper-Hughes and Lock 
1987). Mary Douglas points towards this as far back as 1966, arguing that a group's demarcation between something pure and something dangerous or impure could be viewed as a result of patriarchal dominance. Thus, as Connolly (2009) states:

"The subsequent conflation of women's bodies with the body politic means that control of their bodies and fertility is key to the maintenance of the group's boundaries and status". (Connolly, 2009: 499)

Gender perspectives, then, have been studied within a Middle Eastern context (Galal 2009). However, the gender perspective is also in evidence regarding interfaith intimacies among MEC migrants situated in Denmark, as we shall see in this article. At least one study concludes that a negative attitude toward relationships between Western ('secular') women marrying male ethnic others of Muslim faith exists even in more secular regions: "Crossing religious and ethnic boundaries generally disturbs conventions and can engender hostility," argues Nieuwkerk (2006: 1) in her study of Western women embracing Islam.

Thus there are many nuances to the tension between MECs and their Muslim compatriots in Denmark. Historical, political, public, social and personal aspects enhance, challenge or jeopardise the narratives of boundary maintenance and the strategies to recover from boundary crossing. In this regard Barth's call for exploring boundary maintenance, as opposed to the content contained by them, makes sense.

\section{A bracelet with a cross and a necklace with Fatima's hand}

Elizabeth is a middle-aged MEC immigrant and has lived in Denmark for many years. When I met her at the interview, she wore a bracelet with a cross and a necklace with Fatima's hand, symbolising how boundary crossing between the two religious groups, and their shared history and geography, is embedded within her life and how she is not afraid to make that physically visible.

Elizabeth has a Muslim boyfriend, with whom she has two adult children. Although her boyfriend now lives in Lebanon, it seems they are still very close and they visit each other whenever they can.

When describing how they met, she calls herself a bandit, encapsulating her position as a naughty child from a parent's perspective and emphasising the humorous distance she has put between herself and the situation, which is now a long time ago. Moreover, the quote emphasises the forbidden aspect of the relationship and her awareness that she broke the rules by falling for a Muslim man and engaging in a relationship with him. 
She is quite frank about the consequences it had, the first and most devastating of which was that her mother broke contact with her immediately after she told her about the relationship. At that time, she had only just started dating this man, and therefore Elizabeth's narrative emphasises that the act of boundary crossing provokes a reaction already at the level of dating. Elizabeth and her mother never did resume contact, not even before her mother died 10 years ago. She tries to explain: "Because we have that culture where you do not marry a Muslim (...) and if (you do), you (the parents/family) just have to leave and forget about it (the family member marrying a Muslim)". Hence, the relationship is forbidden according to the family, but also by the cultural community to which they belong, namely the MEC community. As such, her mother felt she had no choice, but was obliged to break contact with her.

When Elizabeth narrates what she told her daughter about the rift, she says: "I did not marry one of my family (a Christian) and then I am out". Thus, Elizabeth is conscious about having crossed a boundary and when she reflects about it, she is straightforward about the consequences and the reasoning behind it: "Now I see that my mother was right - when you marry a Muslim you can never agree; there will always be conflict" and in a sarcastic tone she says she might consider doing the same with her daughters, even though I think it is meant as a joke, to justify her mother's decision.

When interviewing Elizabeth she seemed surprisingly calm when talking about the situation, and she often brought the subject into play on her own initiative. It felt like she had come to terms with the circumstances a long time ago and now acknowledged the hidden rules within the community and family regarding intimate relations with Muslims and the consequences of breaking them. It did not seem taboo for her to talk about it; rather, she cast a comic light on her intimate boundary crossing and the consequences it had. As Jackson (2012) argues: the tragic and the comic are terms that mark the opposite ends of a continuum in the process of recovery. After the passage of enough time, Elizabeth's narrative exhibits signs of recovery. What must have been experienced as quite tragic - the loss of contact with her beloved mother - is a situation she is now able to joke about.

It is important to mention, though, that Elizabeth does not have any religious or social bonds with the established Middle Eastern Churches or communities in Denmark. She practices a solitary form of religious belonging in a Danish Lutheran cathedral, where she uses the church room as a meaningful space (Cresswell, 2015) to sit and pray and light candles, thus producing her Christian identity, which is not produced in any other places or social contexts in her life. Therefore, she is not positioned as a member within a specific MEC community in Denmark and hence has no duties, rights or obligations ithin the community (Tan \& Moghaddam 1999). Thus, she is able to 
speak her mind without thinking of any social consequences from the community because she has never been affiliated with one in Denmark. The time of being involved in a community was long ago and as a child and teenager in the Middle East. At the end of the interview, when I tell her about my own motivation for interviewing her - namely the fact that she is not affiliated with an MEC community - she says: "Yes, I am very different. If for example you interview other Christians in other churches, then you will see something completely different, not like me." Hence, with selfawareness she positions herself outside the MEC community in Denmark in general. Here you could question why Elizabeth's narrative is important in this analysis at all, when she expresses no sense of belonging to the MEC communities in Denmark. I return to this point later.

Besides having a Muslim boyfriend for many years, her best friends are Lebanese Shia Muslims. She has no MEC friends, besides her relatives in Sweden. When I ask her if all her friends are Muslim, she says: "Yes yes, I have the best friends, even though we are...." The sentence is cut of as if she needs words and hence the sentence contain an implicit 'but' which covers the specific and salient difference or boundary between her and her group of friends, namely a religious demarcation.

Elizabeth has many family members in Sweden, who are much engaged with the MEC communities there. When arriving in Denmark as an asylum-seeker with her mother, they intended to go all the way to Sweden, but they were caught by the Danish police and registered in Denmark and thus, they were given asylum in Denmark instead. And in that regard she says: "I say thank God, because I would not have liked it in Sweden. I have been there many times and I do not like it." Elizabeth does not have much contact with the relatives in Sweden and it remains an unanswered question why she does not like it there. She herself emphasises her lack of social needs in general and how she likes to be alone. However, I would argue that this is an indication of recovery since she does not miss the contact with MEC communities and she displays no regret as to how her life has turned out. She somehow uses her Shia friends in Denmark as an alternative, arguing that there is no need to join the family and relatives in Sweden, as she has her close circle in Denmark. Therefore I argue that her Shia friends are considered more able to embrace her intimate boundary crossing and her ambivalent notions of belonging than her relatives in Sweden; together with her friends she travels to Lebanon; they often visit each other and dine together, and her best friend even goes to church with her sometimes, even though she is a Muslim.

We can assume no simple one-to-one relationship between ethnic units and cultural similarities and difference. The features that are taken into account are not the sum of 'objective' difference, but only those which the actors themselves regard as significant (...) 
Some cultural features are used by the actors as signals and emblems of differences, others are ignored, and in some relationships radical differences are played down and denied. (Barth 1969: 14)

There is no doubt that Elizabeth put a lot of emphasis on her Christian identification and argues that she will never become a Muslim: "I am born Christian and I will die Christian." Using Barth's terminology, religious identification becomes an important difference between her and her Lebanese Shia Muslim boyfriend and friends in Denmark in her narrative. However, in practice I would argue that she plays down the difference and practices a more diverse and fluid transition between the religious demarcations. As an example, she talks much about her inspiration from the Shia Muslim history and culture and reads a lot of Imam Ali's texts and the Quran: She says: "I love Imam Ali." Furthermore, she is very supportive of the Hizbollah movement in Lebanon, arguing that they protect the MECs in the region and that Lebanon is now the only safe haven for Christians in the Middle East. Thus, the boundary is very fluid between her Christian identification and her notion of belonging to a Lebanese Shia Muslim community. Another example arises when discussing national identity at the end of the interview. She argues that she is equally Iraqi and Lebanese, but she does not identify with an Arab ethnicity; she subscribes to a Middle Eastern ethnic identification, able to embrace her ambivalent notions of belonging to a past and imagined Iraqi Christian community and to the newly adopted Lebanese Shia Muslim community.

Having a Middle Eastern appearance, being well read in Islamic literature and having almost exclusively Muslim friends and no attachment to MEC communities in Denmark, she becomes almost invisible as a Christian, which makes her able to practice a fluid transition between the two groups. An example of this is when she describes her relations with a Muslim colleague at work, with whom she often discusses Islam. After having worked together many years it is revealed to him that she is not Muslim but Christian, and she says:

"He said: 'What?' I say 'Yes, I am not a Muslim, but it is fine we can talk and we can discuss (the subject of Islam).' Of course he had a shock and he said to me: 'Elizabeth, you are not Christian but you are better than a Muslim, because you have read and know everything (...).' But I will never be Muslim of course - I read, I have it - I love Imam Ali, but I will never be."

Thus, she is actually able to pass as a Muslim and she is considered 'the same' until she reveals her religious identification as a Christian. The invisibility allows her to maintain agency in regard to boundary maintenance and boundary crossing. I argue that by practicing a solitary form of religious belonging and identity, and by positioning herself as detached from her family in Sweden and MEC communities 
over there, she carves out her right to determine when she wants to cross the boundary and when she wants to maintain it, and that is why her unique narrative is so important in this analysis.

The boundary is crossed when engaging with Shia Muslims, who are considered as allies in Elizabeth's narrative and as having a joint history with Christians in the Middle East. As she explains: "I grew up with them (Shia Muslims in Iraq) and I was very happy about it," meaning they have always been a part of her life in a positive way and therefore it is natural for her to continue the relationship with them. Shia Muslims protect Christians in the Middle East and share the same cruel fate in Iraq these days in attacks from ISIS, as Elizabeth explains, and thus one can engage with Shia Muslims without being robbed of one's religious identification as a Christian: they are able to live side by side with mutual respect for each others' religious differences. Implicitly, it would be different trying to engage with Sunni Muslims, seen as the ones behind ISIS.

However, she argues that ISIS should not be able to call themselves Muslims: "They do not have anything to do with religion, they are just criminal people." As such, she does not explicitly express distance from Sunni Muslims, but it is implicit in the way she keeps reiterating the boundary between Shia and Sunni Muslims, whom she consider dangerous to Christian communities in the Middle East and dangerous to MECs in Denmark, when she tells about being harassed by them and having felt threatened when wearing her cross around her wrist.

To conclude, Elizabeth practices rather dynamic boundaries between the two groups and they are constantly negotiated within her narrative, although in a very calm way as if she can easily move back and forth when crossing boundaries. What is most remarkable is how she has recovered from the intimate interfaith boundary crossing in her younger years, by feeling strongly involved with Lebanese Shia Muslims and having become almost 'the same', by adopting shared political, cultural and national/regional identification with Lebanese Shia Muslims. However, the religious identification as a Christian is constantly salient in the narrative, and a demarcation between her solitary Christian life and her social Shia Muslim life.

Thus, the intimate boundary crossing is what positions her outside the MEC communities in Sweden and her family in the first place, but she has recovered from the loss by engaging in new meaningful social networks that are able to embrace her ambivalent notions of belonging, namely the Shia communities, and now she experiences a freedom to cross boundaries or maintain them whenever she wishes.

Elizabeth's body and intimate relations with a Muslim man became political, and her mother and others affiliated with MEC communities were forced to break contact with her in order to survive (Connolly 2009). Somehow she recovered by adopting a new and 
meaningful notion of belonging to a Shia Muslim community without having to sacrifice her sense of religious identification as an MEC. As such, she can speak freely about it and shed a comic light on her story on interfaith intimate boundary crossing.

\section{The parental position}

The narratives of Mariam and Aaron are very different to Elizabeth's narrative. They are both in the middle of a situation where a daughter is dating a Muslim man in Denmark, and both narratives are highly marked as stories of suffering and tragedy with themselves at the centre, whereas Elizabeth has put the tragedy far behind her after a long recovery period. As such, their stories do not have the same comic distance to interfaith intimate boundary crossing and, importantly, they are not the ones acting, but rather the ones acted upon (Jackson 2012: 35) because of their relational bonds with those acting. As Jackson puts it:

"Storytelling (...) (allows) us to feel that we actively participate in a world that for a moment seemed to discount, demean, and disempower us". (Jackson, 2012: 35)

That became rather salient when Mariam asked me to help her persuade her daughter to stop seeing her Muslim boyfriend when I interviewed her. She was desperate to solve the situation and felt deeply disempowered and extremely affected by the consequences of her daughter's interfaith intimate boundary crossing, since the community had socially excluded her and moreover, her own contact with her daughter had become restricted. As such, she partly used the interview and storytelling as a strategy to seek help, allowing her to feel that she could actively do something about her situation.

The same strategy was not as strongly in evidence when interviewing Aaron, although he felt furious about the situation: "She is in love with $a-$ he is a Muslim and we hate Muslims you know, because if there were no Muslims in our country we would not have moved, so we hate them now - much." Very explicitly, Aaron regards his daughter's relationship with a Muslim man as a general and symbolic betrayal of MECs. The romantic relation becomes a break of a clear demarcation between Us (as Christians) and Them (as Muslims). The relation becomes political and the daughter's body becomes political (Connolly 2009).

Generally, Aaron's narrative bears the mark of being a history of suffering. The narrative carries a number of examples of how Muslim compatriots had destroyed elements of Aaron's life and left him feeling robbed. An example he cites is how his father's shop in the Middle East was destroyed by Muslims. He emphasises how almost 
no Christians are left in his previous homeland because of Muslims. This story carries the same Islamophobic views as other MEC narratives; a view that history repeats itself when Muslims seize Christian domains. He argues that they will take over Denmark also, exemplifying it with the allowance of building mosques in Nørrebro. So the fact that Muslims have now even taken his daughter confirms his suspicion and underpins his distrust. There is no doubt that he carries strong anti-Muslim feelings and that he does not distinguish between good and bad Muslims: they are all bad in his opinion and you can never trust them. He regards the motive of the Muslim boyfriend for starting the relationship with his daughter as having nothing to do with love and he says: "And man Muslim, if he marry Christian, he say oh it is very good because he goes to Paradise." Thus, the incentive for being romantically involved with his daughter is to fulfill his Muslim missionary task so that he is able to go to heaven, which again is symbolic of how Muslims seize his and other Christians' domains; his daughter's body is thus his and the MEC community's domain.

Mariam, who is in the same situation - having a daughter with a Muslim boyfriend in Denmark - is more nuanced towards Muslims. She says: "I had problems with Muslims, but we have many Muslims (who) are very, very good." However, Mariam is very disturbed by the fact that her daughter has a Muslim boyfriend and she fears that her daughter has already converted: "I do not know what has happened to her, she is not behaving as she used to and she is totally different, because she - well - she wears (blouses with) long sleeves, well like Muslims and she does not like to eat pork." Mariam tried asking the police in Denmark for help with getting her daughter to end the relationship, but the police were confused about the request, since her daughter is over 18 years, the legal age of consent (myndig in Danish). Mariam savours the word myndig twice as though she was trying to pronounce it correctly, emphasising the fact that this term was alien to her, and she says: "Yes, you can't do anything because your daughter is now xx years - not like in Iraq where it is yes or no." She explains how in Iraq, the parents can decide who your daughter is allowed to marry; in other words, you do not have a term like myndig determining a legal age. This is an example of how an immigration context situates the interfaith intimate boundary crossing differently than if it had occurred in the Middle East, where legislation is much more sensitive towards religious differences as well as to parents' rights to control their children's partner choices than in Denmark. She sought help from the state authorities; however she was only met with an uncomprehending attitude from the police. They actually ended up helping the daughter by convincing the mother (Mariam) that she could not do anything about it. Even Mariam's psychologist neglected the problem. Mariam says: 
"Also I speak with my psychologist and she said to me, it is no problem, Muslim or Christian it is the same God. I said to her no! Christians are different from Muslims."

Mariam's struggle for boundary maintenance is affected by state policy. Her status as a mother has been stripped of agency, and this gives rise to a sense of powerlessness in Mariam's narrative, because she is affected by her daughter's intimate relations with a Muslim man. In the MEC community she used to be part of, she is now experiencing the same kind of informal social exclusion that Aaron describes - the feeling that other members of the MEC community are distancing themselves. Consequently, she feels forced to leave the community and find another place to practice religious belonging.

Aaron, like Elizabeth, is quite frank that he and the rest of the family would have to break contact with their daughter in the near future in order to regain membership of the MEC community, unless she ends the intimate relation with the Muslim man.

To conclude, while the narratives of Mariam and Aaron offer a different perspective to Elizabeth's on intra-ethnic interfaith intimacies between MECs and Muslims, they all show that one woman's interfaith intimate boundary crossing affects not only herself, but also the parents, since her individual choice of boyfriend affects her parents' position in the MEC community. Second, we see how the parents end up in a situation where they have to follow community policy - namely break contact with their daughter - in order not to pose a threat to the community. Therefore the body of the woman becomes political, at both family and community level; the struggle to maintain boundaries becomes the community's struggle to survive.

\section{Conclusion}

Through the analysis of three narratives of MECs having experienced the consequences of interfaith intimate boundary crossing with Muslims several points have been made.

First of all, the boundary crossing becomes problematic and causes a threat to the individual, family and MEC community already at the stage of dating, since all three narratives regarded romantic relations and not legal marriages. Moreover, in all three cases it was daughters dating Muslim men, and thus it is possible to argue that this is not just coincidental with reference to previous studies on gendered matters of intimate boundary crossing.

Secondly, the boundary crossing is situated differently in an immigrant context than in the Middle East. From one point of view this offers an invisibility that allows fluid boundaries between the religious groups, as in the case of Elizabeth, who benefited from this 
possibility, whereas from another point of view it can be experienced as constraining and disempowering, as in the case of Mariam when she was left with nowhere to turn once official solutions to the problem with her daughter had failed.

Third, the MEC communities are already struggling for survival as an invisible institution. The enhanced minority status leaves an individual young woman with one option: leave your Muslim boyfriend or be excluded from the community. If a daughter does not leave her boyfriend, the parents are faced with a similar option: break contact with your daughter or the community will break contact with you. Thus, belonging to a community leaves an individual - or family - with rather inflexible demarcations of boundaries and consequently there is little space for negotiating boundaries between the two religious groups; the policy of the community defines them. If you are not a member of a specific MEC community, like Elizabeth, you are able to produce dynamic and fluid boundaries between the two religious groups and you are allowed to negotiate the boundary constantly.

What is interesting in this research is how the Muslim-Christian relation is negotiated within new frames, which are not based on ethnic differences but religious ones. Equally fascinating is how an invisible community within an ethnic group struggles for survival by controlling intimacies with 'the significant other' group in a new political environment that almost completely disregards religious differences. The new frames offer new insights into MuslimChristian relations and into the changes in fluidity of boundaries between the two groups, depending on whether one is an individual, relatively independent of a community, or struggling for survival. However, this research is very limited and it is hard to conclude anything on the basis of only three interviews. For this reason I strongly recommend more research on the subject of intra-ethnic interfaith intimate boundary crossing in an immigrant European context.

\section{Author biography}

Anne Rosenlund Jørgensen is MA in Middle East Studies from University of Southern Denmark. She has been part of the Danish component of the research program Defining and Identifying Middle Eastern Christians in Europe as intern, student assistant and research assistant and she wrote her Masters' Thesis on the basis of her involvement in this research of Middle Eastern Christians in Denmark. Her focus has been on MECs practicing religiosity outside the established MEC communities in Denmark. 


\section{References}

Anthias, Floya and Nira Yuval-Davis, 1989: Introduction. In: Nira Yuval-Davies and Floya Anthias: Woman-Nation-State. Macmillan: $1-15$.

Barth, Frederik, 1969: Introduction. In: Barth, Frederik: Ethnic Groups and Boundaries: The Social Organisation of Cultural Difference. Universitetsforlaget, Oslo Universitet.

Barth, Fredrik, 1994: "Enduring and Emerging Issues in the Analysis of Ethnicity", In: Vermeulen, Hans and Cora Govers The Anthropology of Ethnicity: Beyond "Ethnic groups and boundaries": 11-32. Amsterdam: Het Spinhus.

Connolly, Jennifer, 2009: "Forbidden Intimacies: Christian-Muslim Intermarriage in East Kalimantan, Indonesia", in American Ethnologist. Vol. 36, No. 3: 492-506.

Cragg, Kenneth, 1991: The Arab Christian: A History in the Middle East. Westminister/John Knox Press.

Douglas, Mary, 1966: Purity and Danger: An Analysis of Concept of Pollution and Taboo. Routledge.

Galal, Lise P., 2012: "Coptic Christian Practices: Formations of Sameness and Difference", in: Islam and Christian-Muslim Relations. Vol. 23 issue 1: 45-58.

Galal, Lise P., 2009: Minoritet, Medborger og Martyr: En Minoritetsteoretisk Analyse af Positioner og Fortællinger Blandt Ortodokse Koptere i Egypten. Ph.d. Dissertation. Roskilde Universitet.

Ginsburg, Faye D. and Rayana Rapp, 1995: Conceiving the New World Order: the Global Politics of Reproduction. University of California Press.

Greene, Molly, 2000: A Shared World: Christians and Muslims in the Early Modern Mediterranean. Princeton University Press.

Hanish, Shak, 2009: Christian, Yazidis, and Mandaeans in Iraq: A Survival Issue. DOMES - Digest of Middle East Studies, Vol. 18, issue 1. pp. 1-16. 
Hasan, Sana S., 2003: Christians versus Muslims in Modern Egypt: The Century-long Struggle for Coptic Equality. Oxford University Press Inc.

Hunter, Alistair and Fiona McCallum, 2014: Translocation of Prejudice: Middle Eastern Christian Islamophobic Discourse in the UK, paper presented at the International Islamophobia Conference, Department of Political Science, University of Salzburg, Salzburg, Austria, $9^{\text {th }}$ October.

Johansen, Tobias S, 2014: "Ekspert: Chikane mod Kristne er et Voksende Problem", in: The Christian Daily. Available online: http://www.kristeligt-dagblad.dk/samfund/2014-09-24/ekspertchikane-mod-kristne-indvandrere-er-ny-form-hadforbrydelse (Accessed 13 November 2015)

Khader, Naser, 2014: "Kristne Arabere Bliver Forfulgt i Danmark", in: Religion.dk. Available Online: http://www.religion.dk/kommentaren/2014-09-15/kristne-araberebliver-forfulgt-i-danmark (Accessed 21 Sep. 2015).

McClintock, Anne, 1997: "No Longer in Future Heaven: Gender, Race, and Nationalism", in: McClintock, Anne, Aamir Mufti, and Ella Shohat: Dangerous Liaisons: Gender, Nation, and Postcolonial Perspectives. University of Minnesota Press: 89-112.

Nieuwkerk, Karin van et. el., 2006: Women Embracing Islam: Gender and Conversion in the West. University of Texas Press.

Poulsen, Pia Lund, 2012: På tværs og på trods: Om Ægteskabsimmigration I Danmark. Frydenlund.

Rytter, Mikkel, 2007: "Partnervalgets Grænse: Dansk-Pakistanske Ægteskabsmigranter i Sverige”, in: Dansk Sociologi, Vol. 3: 25-46.

Scheper-Hughes, Nancy and Margaret M. Lock, 1987: "The Mindful Body: A Prolegomenon to Future Work in Medical Anthropology", In: Medical Anthropology Quarterly (n.s.). Vol. 1, issue 1: 6-41.

Schmidt, Garbi, 2011: "Law and Identity: Transnational Arranged Marriages and the Boundaries of Danishness. Journal of Ethnic and Migration Studies”, in: vol 37, issue 2: 257-275.

Singla, Rashmi, 2015: Intermarriage and Mixed Parenting, Promoting Mental Health and Wellbeing: Crossover Love. Palgrave Macmillan. 
Song, Miri, 2012: “Making Sense of 'Mixture': States and the Classification of 'Mixed' People", in: Ethnic and Racial Studies. Vol. 35, issue 4: 565-573.

Sparre, Sara L., Anne R. Jørgensen \& Lise P. Galal, Forthcoming, 2016: "Domestication of Difference: Practices of citizenship among Middle Eastern Christians in Denmark", in McCallum, Fiona, Lise P. Galal, Alistair Hunter, Sara L. Sparre and Marta Wozniak (eds.). Middle Eastern Christians in Europe. London: Routledge.

Sparre et. al., 2015: Middle Eastern Christians in Europe: Histories, Cultures and Communities. University of St. Andrews. Available online:https://arts.st-andrews.ac.uk/dimecce/?page_id=1207

(Accessed 13 November 2015)

Tan, Sui-Lan \& F. M. Moghaddam, 1999: "Positioning in Intergroup Relations”. In: Harré, Rom \& Luk van Langenhove: Positioning Theory, Blackwell Publishers Ltd. 